\title{
Vertical Chlorophyll-a Concentration Profiles Observed on The Western Coast of Northern Sumatera During the 2017 Northeast Monsoon
}

\author{
Iskhaq Iskandar*, Qurnia Wulan Sari ${ }^{2}$, Aan Johan Wahyudi ${ }^{3}$, Afdal $^{3}$, Wijaya Mardiansyah ${ }^{1}$ \\ ${ }^{1}$ Department of Physics, Faculty of Mathematics and Natural Sciences, Sriwijaya University, Palembang 30662, Indonesia \\ ${ }^{2}$ Department of Marine Science, Faculty of Fishery and Marine Science, Padjadjaran University, West Java 40600, Indonesia \\ ${ }^{3}$ Research Center for Oceanography, Indonesian Isntitute of Science, Jakarta 14430, Indonesia \\ ${ }^{*}$ Corresponding author: iskhaq@mipa.unsri.ac.id
}

\begin{abstract} be high, ranging from 0.2 to $0.25 \mathrm{mg} \cdot \mathrm{m}^{-3}$.

Keywords

Deep Chlorophyll-a Maximum, E-WIN Cruise, MODIS Aqua, Surface Chlorophyll-a
\end{abstract}

Subsurface chlorophyll-a (chl-a) concentration variability on Sumatera's Northwestern coast is part of the phytoplankton biomass that supports and enriches the region's fisheries supplies. During the 2017 northeast monsoon season from $25^{\text {th }}$ November 25 to $11^{\text {th }}$ December, the Ekspedisi Widya Nusantara (E-WIN) collected data from 16 stations. The finding demonstrates a rise in subsurface chl-a concentration as you get closer to the coast. Furthermore, the deep chl-a maximum (DCM) is only found offshore, with depths between 30 to $50 \mathrm{~m}$ and chl-a concentrations of 0.07 to $0.25 \mathrm{mg} \cdot \mathrm{m}^{-3}$. Surface chl-a concentrations near the coast were found to

Received: 20 September 2021, Accepted: 11 December 2021

https://doi.org/10.26554/sti .2022.7.1.36-40

\section{INTRODUCTION}

Located in the tropical Indian Ocean, the Northern Sumatera region is subject to the monsoon system. It has been known that the monsoon system can generate upwelling/downwelling process along the coast. Monsoon systems are thought to play a significant impact in ocean circulation in this area, according to previous research (Sari et al., 2018). The change of ocean circulation as well as nutrient source could affect marine food chain and fisheries production. The concentration of chlorophyll-a (chl-a) has been proposed as the best proxy for phytoplankton biomass, making it valuable for the study of primary production (Huot et al., 2007). It should be noted that this study was conducted for the subtropical water with warm temperature. The photosynthetic parameters and thus primary productivity depend on the environmental variables. The primary productivity response may differ depending on the geography. Surface chl-a, for example, accounts for around $51 \%$ of the entire variance in integrated primary output in the Argentine seas (Lutz et al., 2010; Segura et al., 2013).

The MODIS satellite data in Northern Sumatera were used to examine the geographical and temporal variations of the surface chl-a (Sari et al., 2018). The results demonstrate that in Northern Sumatera during the peak of boreal fall (boreal summer), the surface chl-a is high (low). Furthermore, the monsoon system and associated atmosphere-ocean interactions in the tropical Pacific, namely the El Niño-Southern Oscillation (ENSO), and in the tropical Indian Ocean, namely the Indian Ocean Dipole (IOD), have a significant impact on the abundance of surface chl-a (Sari et al., 2018; Siswanto et al., 2015).

Chl-a maximum is not usually found at the sea surface, but it can also be found deeper than the euphotic zone's bottom. The chl-a maximum cannot be measured using satellite remote sensing in this circumstance. Moreover, seasonal and annual variations of surface chl-a represent unique spatial patterns on a global scale, according to satellite ocean color studies. On regional scales, satellite ocean color studies indicated a strong annual cycle of surface chl-a in the southeastern tropical Indian Ocean and Northern Sumatera, resembling subtropical or temperate regions (Susanto et al., 2006; Siswanto et al., 2017; Iskandar et al., 2009; Amri et al., 2014; Sari et al., 2018).

In this paper, we used vertically observed chl-a concentration from the E-WIN cruise during early of the 2017 northeast monsoon season in the western coast of Northern Sumatera region. The goal of this research is to look at the vertical patterns of chl-a concentration along the cruise track in Sumatera's Northern portion. The rest of the paper is laid out as follows. The study area, data, and techniques are all described in Section 
2. In Section 3, we describe and discuss the study's primary findings. The study's result is presented in the final part.

\section{EXPERIMENTAL SECTION}

\subsection{Materials}

The research area is located between $12^{\circ} \mathrm{N}-3^{\circ} \mathrm{S}$ and $90^{\circ} \mathrm{E}-$ $102^{\circ} \mathrm{E}$ on the western coast of northern part of Sumatera (Figure 1). The E-WIN cruise was conducted from 25 November to 11 December 2017 using the RV. Baruna Jaya VIII of the Indonesian Institute of Sciences. The cruise started from the station E1 near Sabang, Aceh to the station E16 in the eastern Simeuleu Island (Figure 1). The cruise tracks are indicated by red line, while the Conductivity-Temperature-Depth (CTD) observation stations are indicated by yellow filled-stars.

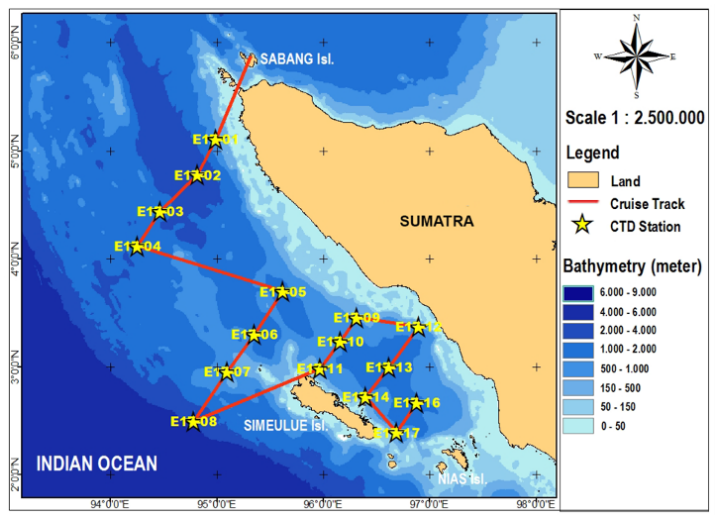

Figure 1. The Transect of The E-WIN Expedition During The Northeast Monsoon of 2017 Is Shown by The Red Line, and The CTD Stations Are Indicated by The Yellow Filled-Circle.

\subsection{Methods}

Chl-a concentrations were sampled at 16 locations along Northern Sumatera's western coast. With a Rosette sampler from Niskin Bottles installed on a Sea-Bird Electronics conductivitytemperature-depth (CTD) type SBE-911 plus, discrete seawater samples were taken from 6 fixed depths $(5,50,75,100$, 150 , and $300 \mathrm{~m}$ ) at each station. Measurements of nutrient concentrations (phosphate, nitrate, and silicate) were carried out using the HACH spectrophotometer (Suzuki et al., 1995). The fluorometric approach was used to measure phytoplankton chl-a concentrations, as recommended by U.S. Environmental Protection Agency (1983). Under a vacuum pump with a pressure less than $30 \mathrm{cmHg}, 0.1-1.0$ liter of water was filtered using the Whatman CNM porous filter with a $0.45 \mathrm{~m}$ and $25 \mathrm{~mm}$ diameter. Before being examined, the membrane filters were stored in a cooler (with temperatures below $4^{\circ} \mathrm{C}$ ) for roughly 20 hours after being wrapped in aluminum foil (U.S. Environmental Protection Agency , 1983). After filtration, the samples were extracted using a 90 percent acetone extraction solution (Cochlan and Hendorn, 2012; Holm-Hansen et al., $1965)$ and centrifuged for 30 minutes at 4,000 rpm to separate the filter from the chl-a-containing solution (Cochlan and Hendorn, 2012; Holm-Hansen et al., 1965). The vertical profiles of fluorescence are then obtained by reading the fluorescent liquid using the AU-10 Turner Trilogy Fluorometer. The concentration of phytoplankton chl-a is defined as,

$$
\operatorname{Chl}-\mathrm{a}(\mu g / L)=((y-b) / m)(v / V)
$$

where $y$ is a fluorescence value, $b$ is the y axis value that intersects the curve calibration, $m$ is a slope of the regression line on the standard curve (calibration), $v$ is a volume of the extract (after addition of acetone $90 \%)(\mathrm{mL})$, and $V$ is the volume of filtered sample $(\mathrm{mL})$.

Using CTD dataset, the mixed layer depth (MLD) was calculated as a depth where the density increases by 0.125 $\mathrm{kg} \cdot \mathrm{m}^{-3}$ from that of the reference point (10 $\mathrm{m}$ deep) Zeng and Wang (2017) as shown in Table 1.

Table 1. Calculated Mixed Layer Depth using Density Criterion

\begin{tabular}{cc}
\hline Station & MLD $(\mathrm{m})$ \\
\hline E017-01 & 31 \\
E017-02 & 20 \\
E017-03 & 21 \\
E017-04 & 15 \\
E017-05 & 20 \\
E017-06 & 25 \\
E017-07 & 14 \\
E017-08 & 50 \\
E017-09 & 25 \\
E017-10 & 22 \\
E017-11 & 31 \\
E017-12 & 18 \\
E017-13 & 23 \\
E017-14 & 24 \\
E017-15 & 12 \\
E017-16 & 19 \\
E017-17 & 31 \\
\hline
\end{tabular}

The in situ data is also compared to the surface chl-a concentration remotely-sensed by the Moderate Resolution Imaging Spectroradiometer (MODIS) aboard the Aqua satellite between $25^{\text {th }}$ November and $18^{\text {th }}$ December 2017. The NASA Goddard Distributed Active Archive Center provided the satellite data, which had a horizontal resolution of $4 \mathrm{~km}$ (https://modi s.gsfc.nasa.gov/).

\section{RESULTS AND DISCUSSION}

\subsection{Vetical Profiles of Chlorphyll-a Concentrations and Flu- orescences}

Based on the distance of stations to the coast, the water characteristics of the western coast of Northern Sumatera can be clustered into two regions (Figure 1), namely the offshore and the coastal waters. The vertical profiles of chl-a along the western coast of Northern Sumatera, along with the vertical profiles 
of the observed fluorescene, were used to identify each observation station in the present study. The fluorescene can be employed as an indicator of chl-a concentration, according to the method proposed in early study (Sauzède et al., 2015; Zhao et al., 2019). The water characteristic with deep chl-a maximum (DCM) and high surface chl-a (HSC) profile data was used to characterize the chl-a visual analysis (Lavigne et al., 2015). Vertical chl-a profiles are often described using the DCM and HSC forms (Lavigne et al., 2015). They are characterized by the relative position of MLD and are referred to as "stratified" and "mixed," respectively. The HSC standard shape was generated for profiles with a continuous decrease in chl-a from surface to depth (approximately $100 \mathrm{~m}$ ), such as those seen during phytoplankton blooms (Chiswell, 2011). Profiles with relatively high values in the mixed layer and a fluoresence peak directly below the MLD are represnted by the DCM form. Table 1 shows that the MLD in the study area was usually between 14 and $50 \mathrm{~m}$. The deepest MLD is at station E017-08, with a depth of $50 \mathrm{~m}$, while the shallowest MLD is at station E017-17, with a depth of $14 \mathrm{~m}$.
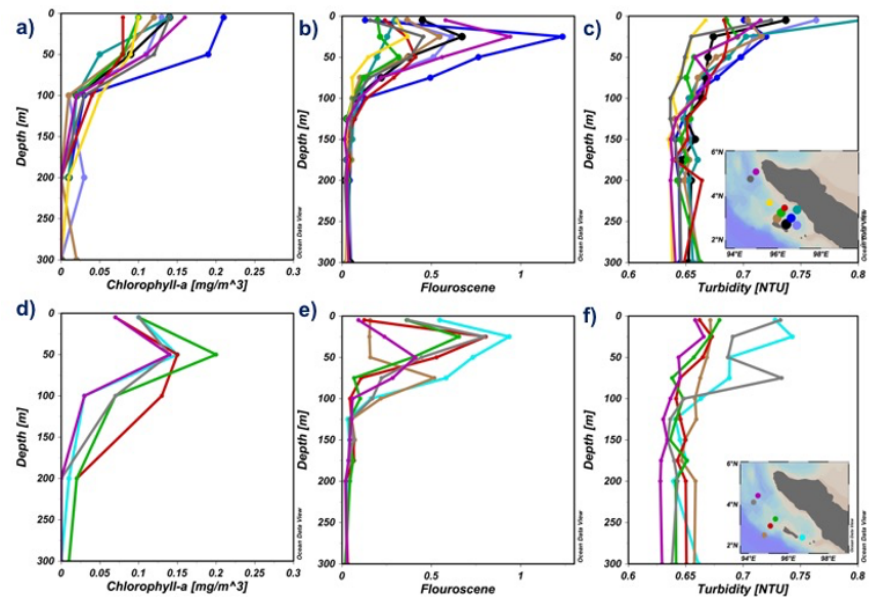

Figure 2. Vertical Profiles of (a, d) Chl-a Concentration, (b, e) Fluorescence, and (c, f) Turbidity. The Classification is Based on Avertical Chl-a Concentration Profile, with The Upper Panel Representing Stations with High Surface Chl-a (HSC), and The Lower Panel Representing The Stations with Deep Chl-a Maximum (DCM)

Figure 2 depicts chl-a concentration, fluorescence, and turbidity profiles in Northern Sumatera waters from the surface to $300 \mathrm{~m}$ depth. Figures $2 \mathrm{a}$ and $2 \mathrm{~d}$ show that the observed profiles of chl-a concentration are remarkably comparable to the profiles of fluorescence (Figures $2 \mathrm{~b}$ and $2 \mathrm{e}$ ). With the exception of station E017-05, where no chl-a was identified in the surface water, the surface chl-a concentration in Northern Sumatera waters was about 0.051 to $0.21 \mathrm{mg} \cdot \mathrm{m}^{-3}$ (Figures $2 \mathrm{a}$ and $2 \mathrm{~d}$ ). This indicates that the Northern Sumatera waters are oligotrophic waters. The high and low concentration of chl-a is closely related to the supply of nutrients originating from the land through the rivers discharge into these areas. The sur- face chl-a concentration was found more at the stations located close to the land than that at the stations located toward the sea. The highest concentration of surface chl-a was found at station E017-13, which lies between the Sumatera and Simelue Island with a value of $0.21 \mathrm{mg} \cdot \mathrm{m}^{-3}$. In the east of Simelue Island, we found turbid waters caused by the presence of suspended particles and high levels of sludge which were carried from the land and rivers around the island. Meanwhile, the lowest concentration of surface chl-a was observed at stations E01703 and E017-07. This is presumably because the location of those stations were heading towards the open sea resulting in little input of nutrients from the land which causes less surface chlorophyll content.

It was confirmed by Figure 2 that the stations located near the coast are having high surface chl-a concentration, while those located offshore tend to have deep chl-a maximum. Moreover, the coastal water is also characterized by high turbid water (Figure 2c). It is worth noting that the land gives a lot of input into the waters. As a result, waters near the land become fertile water which will ultimately be beneficial for phytoplankton to carry out photosynthetic activity. Previous study has suggested that river runoff significantly affect the content of nutrients (Phosphate, Nitrate and Silicate) in the ocean (Zhang et al., 2020). In addition, it can inferred aslo from Figures 2 that high chl-a concentrations are found at the stations located around the estuary (stations E017-11 and E017-17). The degree of acidity $(\mathrm{pH})$ and nitrate play vital roles in the aquatic environment's health. $\mathrm{pH}$ fluctuations have an impact on chemical processes and biological organisms in the water as well as the toxicity of a chemical compound in water. The $\mathrm{pH}$ of water has a significant impact on its metabolic activities, for example, if the $\mathrm{pH}$ is too low, nitrification will cease (Le et al., 2019). While nitrate is a key component of primary productivity, it is also consumed by phytoplankton and is required for photosynthesis (Li et al., 2010).
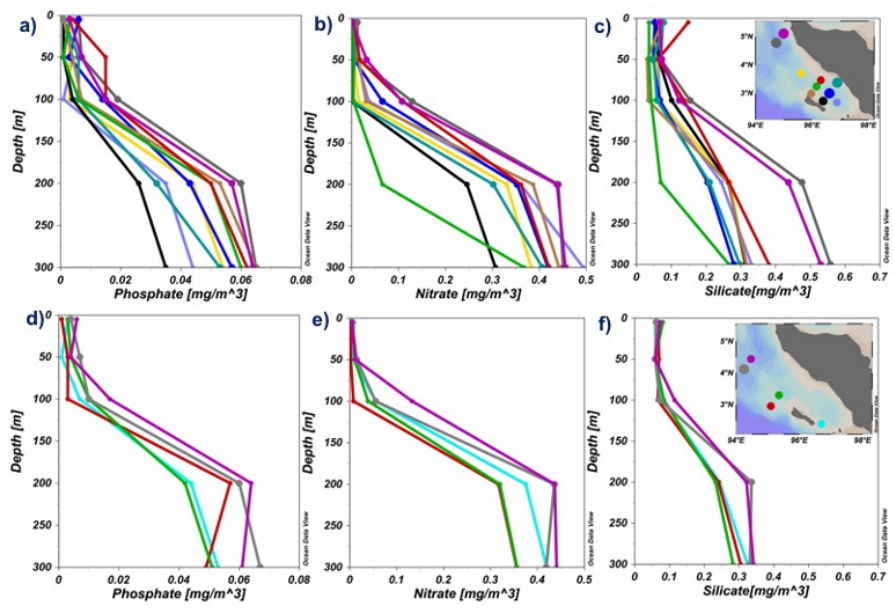

Figure 3. Same as Figure 2 Except for Vertical Profiles of (a, d) Phosphate, (b, e) Nitrate, and (c, f) Silicate.

Phosphate, nitrate, and silicate vertical profiles are shown in 
Figure 3. Phosphate has a vertical profile that ranges from 0.01 $\mathrm{mg} . \mathrm{m}^{-3}$ at the surface to $0.063 \mathrm{mg} \cdot \mathrm{m}^{-3}$ at $300 \mathrm{~m}$ depth (Figures $3 \mathrm{a}, \mathrm{d}$ ), while nitrate has a vertical profile that ranges from 0 near the surface to $0.49 \mathrm{mg} . \mathrm{m}^{-3}$ at $300 \mathrm{~m}$ depth (Figures $3 \mathrm{a}$, d) (Figures $3 \mathrm{~b}, \mathrm{e}$ ). Silicate has a vertical profile ranging from $0.05 \mathrm{mg} . \mathrm{m}^{-3}$ near the surface to $0.57 \mathrm{mg} . \mathrm{m}^{-3}$ at $300 \mathrm{~m}$ underground (Figures $3 \mathrm{c}, \mathrm{f}$ ). There was no discernible difference in the vertical profiles of phosphate, nitrate, and silicate between the stations along the coast and those offshore, according to our findings.

\subsection{The Weekly Satellite Surface Chl-a Distributions}

We showed the distribution of surface chl-a before, during, and after sampling in this study. Due to cloud cover, satellite image quality was poor from $25^{\text {th }}$ November to $2^{\text {nd }}$ December 2017. The satellite measurement nicely recorded the surface chl-a concentration during the sample (December 3-10, 2017) and after the sampling (December 11-18, 2017) (Figure 4). The concentration of surface chl-a near the coast $\left(0.3-1 \mathrm{mg} \cdot \mathrm{m}^{-3}\right)$ is clearly higher than in the offshore area $\left(0.10-0.2 \mathrm{mg} \cdot \mathrm{m}^{-3}\right)$, which is consistent with our in-situ observation.

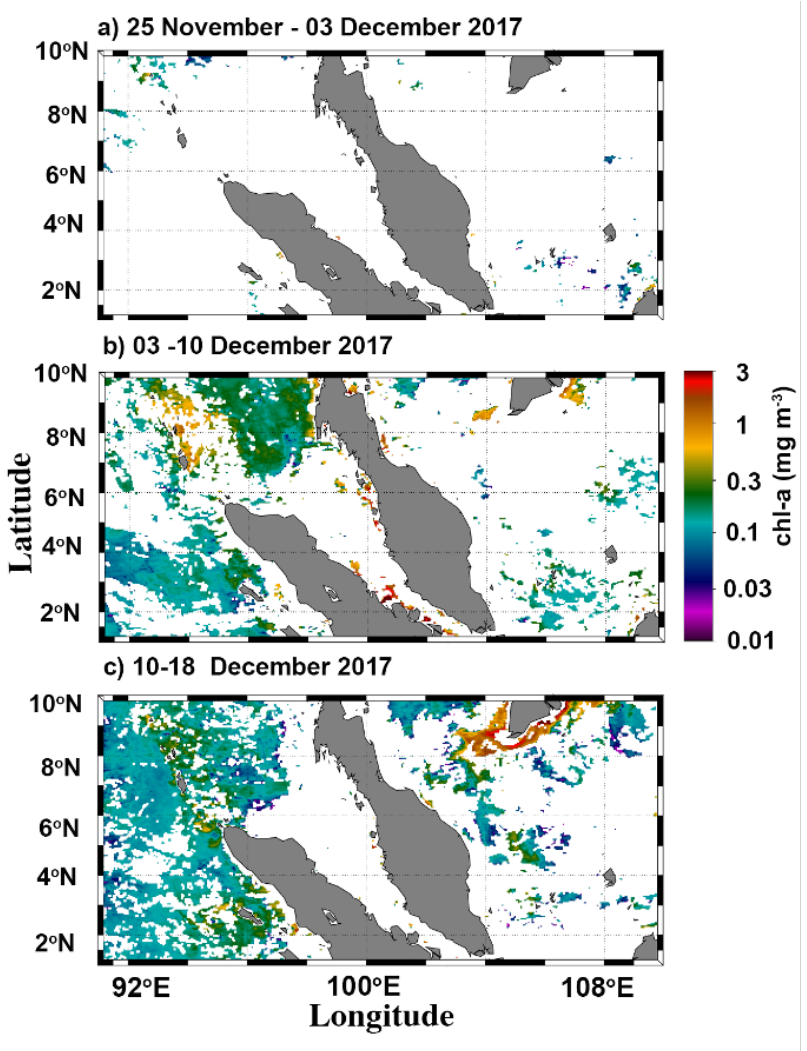

Figure 4. Weekly Composite of Surface Chl-a Derived from MODIS During a) 25 November-03 December 2017, b) 03-10 December 2017 and, c) 10-18 December 2017.

\section{CONCLUSIONS}

Based on in-situ observations obtained during the E-WIN cruise from $25^{\text {th }}$ November to $11^{\text {th }}$ December 2017, this study analyzed the vertical profile of chl-a concentration in Northwestern Sumatera. Discrete seawater samples were taken at depths ranging from 5 to $300 \mathrm{~m}$. Note that while the HACH spectrophotometer was used to assess nutrient concentrations (phosphate, nitrate, and silicate), the fluorometric technique was used to detect phytoplankton chl-a concentrations.

The results reveal geographical differences in vertical chl-a concentrations, with high surface chl-a concentrations found near the shoreline and DCM detected offshore. Station E01713, located between Sumatera and Simelue Island, had the highest surface chl-a concentration of $0.21 \mathrm{mg} \cdot \mathrm{m}^{-3}$. The lowest surface chl-a concentrations, on the other hand, were found at open-sea stations E03 and E017-07. Furthermore, the staellite pictures confirmed that chl-a concentrations in the coastal zone range from 0.30 to $1 \mathrm{mg} \cdot \mathrm{m}^{-3}$, which is higher than the 0.10 to $0.2 \mathrm{mg} . \mathrm{m}^{-3}$ seen offshore. The vertical profiles of phosphate, nitrate, and silicate showed no substantial regional variation.

\section{ACKNOWLEDGEMENT}

The authors thank to the Indonesian Institutes of Sciences (LIPI) through EWIN cruise 2017. This study is supported by the Ministry of Education, Culture, Research and Technology, Indonesia through the Penelitian dasar Unggulan Perguruan Tinggi (PDUPT) 2021 (Contract Number: 150/E4.1/AK.04.P $\mathrm{T} / 2021$ ). The third author (AJW) is supported by the LIPIJSPS Joint Research Grant (JPJSBP120198201) entitled Indian Ocean variability and its impact on climate and ecosystems of the maritime continent (2019-2022).

\section{REFERENCES}

Amri, K., A. Priatna, and S. Suprapto (2014). Oceanographic characteristics and abundance of phytoplankton in the waters of the Sunda Strait in the east monsoon. Bawal Widya Riset Perikanan Tangkap, 6(1); 11-20

Chiswell, S. M. (2011). Annual cycles and spring blooms in phytoplankton: don't abandon Sverdrup completely. Marine Ecology Progress Series, 443; 39-50

Cochlan, W. and J. Hendorn (2012). Water quality methods. Tiburon: Romberg Tiburon Center for Environmental Studies, San Fransisco State University; 317.

Holm-Hansen, O., C. J. Lorenzen, R. W. Holmes, and J. D. Strickland (1965). Fluorometric determination of chlorophyll. Journal of Marine Science, 30(1); 3-15

Huot, Y., M. Babin, F. Bruyant, C. Grob, M. Twardowski, and H. Claustre (2007). Does chlorophyll a provide the best index of phytoplankton biomass for primary productivity studies Biogeosciences Discussions, 4(2); 707-745

Iskandar, I., S. Rao, and T. Tozuka (2009). Chlorophyll-a bloom along the southern coasts of Java and Sumatra during 
2006. International Journal of Remote Sensing, 30(3); 663671

Lavigne, H., F. D'ortenzio, M. Ribera D’Alcalà, H. Claustre, R. Sauzède, and M. Gacic (2015). On the vertical distribution of the chlorophyll a concentration in the Mediterranean Sea: a basin-scale and seasonal approach. Biogeosciences, 12(16); 5021-5039

Le, T. T. H., J. Fettig, and G. Meon (2019). Kinetics and simulation of nitrification at various $\mathrm{pH}$ values of a polluted river in the tropics. Ecohydrology $\mathcal{E}$ Hydrobiology, 19(1); $54-65$

Li, W. K., M. R. Lewis, and W. G. Harrison (2010). Multiscalarity of the nutrient-chlorophyll relationship in coastal phytoplankton. Estuaries and Coasts, 33(2); 440-447

Lutz, V. A., V. Segura, A. I. Dogliotti, D. A. Gagliardini, A. A. Bianchi, and C. F. Balestrini (2010). Primary production in the Argentine Sea during spring estimated by field and satellite models. Journal of Plankton Research, 32(2); 181195

Kumar, S. P, M. Nuncio, J. Narvekar, (2004). Are eddies nature's trigger to enhance biological productivity in the Bay of Bengal Geophysical Research Letters, 31(7); 1-8

Sari, Q. W., P. A. Utari, D. Setiabudidaya, I. Yustian, E. Siswanto, and I. Iskandar (2018). Variability of surface chlorophyll-a distributions in the northwestern coast of Sumatra revealed by MODIS. In Journal of Physics: Conference Series, 1080; 012045

Sauzède, R., H. Lavigne., H. Claustre., J. Uitz., C. Schmechtig., F. d'Ortenzio., C. Guinet, and S. Pesant (2015). Vertical distribution of chlorophyll a concentration and phytoplankton community composition from in situ fluorescence profiles: a first database for the global ocean. Earth System Science Data, $7(2) ; 261-273$

Segura, V., V. A. Lutz, A. Dogliotti, R. I. Silva, R. M. Negri,
R. Akselman, and H. Benavides (2013). Phytoplankton types and primary production in the Argentine Sea. Marine Ecology Progress Series, 491; 15-31

Siswanto, E., K. Matsumoto, M. C. Honda, T. Fujiki, K. Sasaoka, and T. Saino (2015). Reappraisal of meridional differences of factors controlling phytoplankton biomass and initial increase preceding seasonal bloom in the northwestern Pacific Ocean. Remote Sensing of Environment, 159; 44-56

Siswanto, E., H. Ye, D. Yamazaki, and D. Tang (2017). Detailed spatiotemporal impacts of El Niño on phytoplankton biomass in the S outh C hina S ea. Journal of Geophysical Research: Oceans, 122(4); 2709-2723

Susanto, R.D., Moore, T.S. and Marra, J (2006). Ocean color variability in the Indonesian Seas during the Sea WiFS era. Geochemistry, Geophysics, Geosystems, 7(5); 1-10

Suzuki, K., N. Handa, H. Kiyosawa, and J. Ishizaka (1995). Distribution of the prochlorophyte Prochlorococcus in the central Pacific Ocean as measured by HPLC. Limnology and Oceanography, 40(5); 983-989

U.S. Environmental Protection Agency (1983). Methods for Chemical Analysis of Water and Wastes. EPA-600/4-79-020: Washington

Zeng, L. and D. Wang (2017). Seasonal variations in the barrier layer in the South China Sea: characteristics, mechanisms and impact of warming. Climate Dynamics, 48(5-6); $1911-$ 1930

Zhang, P., J.-L. Xu, J.-B. Zhang, J.-X. Li, Y.-C. Zhang, Y. Li, and X.-Q. Luo (2020). Spatiotemporal Dissolved Silicate Variation, Sources, and Behavior in the Eutrophic Zhanjiang Bay, China. Water, 12(12); 3586

Zhao, C., J. Maerz, R. Hofmeister, R. Röttgers, K. Wirtz, R. Riethmüller, and C. Schrum (2019). Characterizing the vertical distribution of chlorophyll a in the German Bight. Continental Shelf Research, 175; 127-146 